\title{
Preheating Of Sunflower Blended Biodiesel for the Improvement of Performance Characteristics of a DI Diesel Engine under Various Loads
}

\author{
Ashok Kumar Mohapatra, Ajit Kumar Senapati, Govind Jha, Chandan Kumar Sharma, \\ Prakash Kumar
}

\begin{abstract}
Due to fast depletion of fuel and for the huge demand of various engine fuels in large sectors and power generation, thse biodiesel which is derived from biological wastes can be a substitute of pure diesel oil. Diesel engine has the benefits of low fuel consumption, high potency, smart economical and dynamic performance. However at the identical time, the diesel engine has high NOx and soot emissions. And these two sorts of emissions provides a trade-off relationship which can bring difficulties to satisfy the necessities of emission rules of NOx and soot. This particular paper primarily reviews regarding using of preheated bio-diesel that contains 20 percentage of pure sunflower oil (biological name-Helianthus annuus) and analyses its performance characteristics for selected blend with completely variable loads. Various experiments were carried out by employing a four stroke single cylinder, direct injection, water cooled diesel engine with suitable specifications. Helianthus oil is mixed with bio diesel for fast burning inside the engine cylinder and by doing so, the Cetane number is quite high that leads to the ignition delay shorter. Therefore the overall content is preheated somewhat in order to lift its temperature so as to boost the burning process. Incorporating to this, it reduces the various emissions such as NOx, CO and smoke capacity by $2 \%$ to $3 \%$. Various parameters are required to outline the analysis of combustion and performance characteristics of the test fuel like brake thermal efficiency(BTE),basic specific fuel consumption(BSFC), basic specific energy consumption (BSEC), temperature of the exhaust gas and emissions like NOx, unburn hydrocarbons(HC), carbon monoxide(CO) and smoke were carried out in the specified engine.
\end{abstract}

Keywords: Diesel Engine, Sunflower oil , Alternative Fuel ,Bio Diesel, Loads, Preheating, Eng Performance of engine, Exhaust emissions.

\section{INTRODUCTION}

An increasing demand of energy and its affect to environmental issue which relates to pollutant emissions have consequently boosted the investigations of various alternative fuels. During the year 1893, the idea of

Revised Manuscript Received on October 30, 2019.

* Correspondence Author

Ashok Kumar Mohapatra*, Assistant Professor, Department of Mechanical Engineering, GIET UNIVERSITY, Gunupur.

Ajit Kumar Senapati, Associate Professor, Department of Mechanica engineering, GIET UNIVERSITY, Gunupur, Odisha

Govind Jha, Bachelor in technology (Fourth year), Department of mechanical engineering at GIET university, Gunupur

Chandan Kumar Sharma, Bachelor in Technology (Fourth year), Department of mechanical Engineering at GIET university, Gunupur.

Prakash Kumar, Bachelor in Technology (Fourth year), Department of Mechanical Engineering at GIET university, Gunupur.

(C) The Authors. Published by Blue Eyes Intelligence Engineering and Sciences Publication (BEIESP). This is an open access article under the CC BY-NC-ND license (http://creativecommons.org/licenses/by-nc-nd/4.0/) implementing vegetable (edible) oil as an alternate source for preparing biodiesel began itself once the diesel engines were introduced at that time. Rudolf Christian Karl diesel, a German inventor firstly used an edible peanut oil as an engine fuel at Paris Exposition during the year 1900.In this context, the combustion, physical and chemical characteristics of vegetable oils are more what nearer to that of diesel oil. After so many researches, vegetable oils could be selected as an instantaneous source to replace for non renewable petroleum fuels. Vegetable oils are renewable energy sources and are eco friendly in nature .These can be easily produced in rural areas and are extracted from seeds. Seeable to this easy production, various scientists from different fields and researchers have initiated their interest towards using vegetable oils as an alternate energy source because of its tremendous characteristics. Any nation is always dependent upon producing its own energy resources for the betterment and development towards various technologies. Regarding to this context, a new idea like conservation of various plant products emerges as a beneficial and eco-friendly work against the depletion of non-renewable petroleum products. On the other hand, as the vegetable oils having remarkable high viscosity and low volatility of , these oils would create many problems like improper combustion, flow of fuel . Poor atomization of fuel particles when directly used in engine with no modifications.

Vegetable oils extracted from plants both edible, crude non edible and Methyl esters (Bio-diesels) are used as alternate source for diesel oil. Biodiesel was found as the best alternate fuel, technically and environmentally acceptable, economically competitive and easily available. Several types of oils that are extensively studied include Sunflower, Soya bean, Peanut, Rapeseed, Rice bran, Karanji etc. One of the disadvantages in using these oils in diesel engines is nozzle deposits, which drastically affects the engine performance and emissions. The refining process of vegetable oil gives better performance compared to crude vegetable oil. The refined vegetable oils has many properties which are very closer to that of diesel oil; however some characteristics like low volatility and high viscosity creates issues when used as an alternate fuel for diesel engines. Many researchers have give ideas regarding to production of crude vegetable oils

which would have given elsewhere in various publications.

Seid Yimer et al.[1] examined the optimization of production of biodiesel by using trans-esterification process with a solid catalyst and compared with the physical properties of diesel oil.

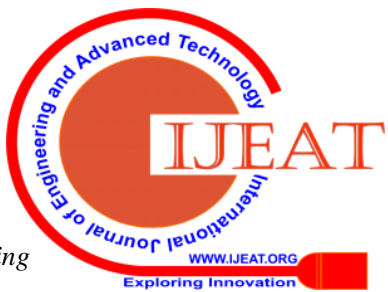


The results shows a tremendous potential of adding the catalyst during the biodiesel production process.

M.M. Hasan et al. [2] studied the performance and emission characteristics of diesel and blended biodiesel and also reviewed what is the environmental and economic impact of biodiesel production. R. Sindhu et al.[3] was investigated the effective reduction of NOx emissions from diesel engine by using split injections and EGR technique. This technique was being found to be effective towards a considerable reduction of NOx emission and also the split injections were noticed to be superior in controlling $\mathrm{NOx}$ emissions as compared to increasing EGR levels. Mithun Das et al. [4] studied the surface tension and viscosity properties of biodiesel blends and their effects on various spray parameters. From this study, The viscosity of the biodiesels are found to be higher than diesel and The surface tension of biodiesel is also found to be higher than diesel at $20{ }^{\circ} \mathrm{C}$. The higher viscosity and surface tension of biodiesels increases the mean droplet size and decreases the cone angle in a fuel spray in comparison to diesel oil.

Menelik Walle Mekonen et al.[5] investigated the influence of preheating on fuel properties of biodiesel and its blends on the performance of a diesel engine along with exhaust gas recirculation (EGR) rate for reducing the NOx. At full load engine testing with same test fuel, BSFC reduces by $19 \%$, BTHE increases by $16 \%$, the exhaust gas temperature (EGT) drops by 6\% with slight increase in volumetric efficiency (2\%).The carbon monoxide and unburned hydrocarbon emission was reduced by $19.5 \%$ and $4.8 \%$, respectively while oxides of nitrogen (NO) emission was increased by $17.5 \%$ compared to diesel fuel.Venu Babu Borugadda et al. [6] investigated the effect of additives like ascorbic acid, Tannic acid, Caffeic acid and tert-Butylhydroquinone on performance of canola biodiesel .This study revealed that the blends of canola biodiesel have shown a significant enhancement in thermal and oxidative stability with natural additives.

The current study on this particular paper examines the use of preheated (up to $60^{\circ} \mathrm{C}$ ) sunflower biodiesel blend (B20) as a test fuel on the performance characteristics and emissions in a direct injection, four stroke, and single cylinder CI engine. The properties of biodiesel oil which was being extracted from pure sunflower oil as shown in Table I.

Table- I: Property Of Biodiesel From Sunflower Oil

\begin{tabular}{|l|c|c|}
\hline $\begin{array}{c}\text { Property of biodiesel from } \\
\text { sunflower oil }\end{array}$ & Units & Value \\
\hline Kinematic viscosity & $\mathrm{mm}^{2} / \mathrm{sec}$ & 4.4 \\
\hline Cetane Number & --- & 49 \\
\hline Lower Heating Value & $\mathrm{MJ} / \mathrm{kg}$ & 33.5 \\
\hline Cloud point & ${ }^{0} \mathrm{C}$ & 1 \\
\hline Pour point & ${ }^{0} \mathrm{C}$ & --- \\
\hline Flash Point & ${ }^{0} \mathrm{C}$ & 183 \\
\hline Density & $\mathrm{Kg} / \mathrm{ltr}$ & 0.860 \\
\hline
\end{tabular}

\section{MATERIALS AND METHODS}

As the viscosity of sunflower oil is higher than that of diesel fuel, it is very essential to reduce viscosity for the analysis of its performance and emissions in the specified diesel engine. Therefore, it is required to modify the sunflower oil. So certain techniques are used to modify vegetable oils to better usable forms. Blending is a straight forward technique of modification during which another liquid with a certain characteristic is mixed to get the average required parameter.

\section{A. Biodiesel Production}

In this study, Firstly the pure sunflower oil was produced by the process of bio-mass pyrolysis . It is a chemical reaction process through which the molecular breakdown of larger molecules into smaller molecules in presence of heat. After that the biodiesel was produced in chemical laboratory by using catalytic trans-esterification process of refined sunflower oil. A process consisting of two steps was used to convert the high free fatty acid (FFA) oil into low FFA biodiesel as the unrefined oil has a (FFA) content up to $16.2 \%$ $(\mathrm{v} / \mathrm{v})$. In the first step, 2\% (vol./vol.) methanol(methyl alcohol) was taken and that is mixed with acid catalyst (4 grams of potassium hydroxide) in a clean glass jar with a tight fitting lid. The mixing process should not take place in a plastic container because the container may dissolve ; Instead it should be in a well-ventilated area, as the methanol fumes are more toxic. After mixing the methanol and catalyst, the methoxide mixture was stirred until the catalyst is completely dissolved. In the second step, One liter of filtered sunflower was taken in a bottle and the methoxide solution was added to the oil. The overall mixture was shaked for about 10 seconds for every 10 minutes three times. The darker layer on the bottom of the bottle is glycerol, the byproduct of the trans-esterification process. These processes were carried out in order to reduce the FFA content in the oil up to $0.5 \%$. For the purpose of reducing the viscosity of the mixture ,it was heated up to $60{ }^{\circ} \mathrm{C}$ for one hour at atmospheric pressure and continuously stirred.

\section{B. Sample Preparation}

Prior to test engine specifications, experiments were conducted firstly with diesel fuel and various parameters were calculated. And for analyzing the emission characteristics, a gas analyzer is being used. A comparison was made when the blends of preheated biodiesel and diesel oil was prepared with different proportions like 20\%, 50\%, $70 \%$ and 100\% biodiesel (B20, B50,B70 and B100 respectively). The specific energy consumption, specific fuel consumption, brake thermal efficiency and emission calculations (NOx, hydrocarbons and smoke) were taken under various loads and at a constant run of the diesel engine without any modifications.

\section{Characterization of Biodiesel}

With regards to the engine tests, four prepared fuels such as pure diesel, pure sunflower oil, sunflower biodiesel (B20) and preheated sunflower biodiesel were characterized using several analytical methods that are listed in Table II.

The equipments were previously calibrated with prepared solutions of biodiesel.

Table- II: Equipments For Characterization

\begin{tabular}{|c|c|c|}
\hline S.N & Property & Equipments used \\
\hline 1 & Density at $15^{\circ} \mathrm{C}$ & Hydrometer/Densimeter \\
\hline 2 & $\begin{array}{c}\text { Kinematic Viscosity at } \\
40^{\circ} \mathrm{C}\end{array}$ & Viscosimeter \\
\hline 3 & Flash point $\left({ }^{\circ} \mathrm{C}\right)$ & Pensky-Martin Apparatus \\
\hline 4 & Fire Point $\left({ }^{\circ} \mathrm{C}\right)$ & Pensky-Martin Apparatus \\
\hline
\end{tabular}




\section{Diesel Engine Setup}

For analyzing the performance and emission characteristics of the prepared testing fuels, an experimental based C.I engine available in our laboratory was taken along with a gas analyzer connected to the exhaust manifold of the engine. The engine specifications are presented in Table III.

Table- III: Diesel Engine Specifications

\begin{tabular}{|c|c|c|}
\hline S.N & Type & $\begin{array}{c}\text { Four-stroke Direct Injection } \\
\text { Diesel Engine }\end{array}$ \\
\hline 1 & Engine & Kirloskar-AV 1 \\
\hline 2 & Type of Cooling & Water Cooling \\
\hline 3 & Bore & $85 \mathrm{~mm}$ \\
\hline 4 & Stroke & $110 \mathrm{~mm}$ \\
\hline 5 & $\begin{array}{l}\text { Displacement } \\
\text { Volume }\end{array}$ & $550 \mathrm{cc}$ \\
\hline 6 & Piston & Hemispherical \\
\hline 7 & $\begin{array}{l}\text { Compression } \\
\text { ratio }\end{array}$ & $1: 16.5$ \\
\hline 8 & Power Rating & $3.75 \mathrm{~kW}$ at $1500 \mathrm{rpm}$ \\
\hline 9 & Rate Of Output & $5 \mathrm{BHP}$ \\
\hline 10 & Fuel Oil & Diesel oil \\
\hline 11 & Type of Governor & Mechanical Centrifugal type \\
\hline 12 & $\begin{array}{l}\text { Lubrication } \\
\text { System } \\
\end{array}$ & Forced Feed type \\
\hline 13 & Holding Device & $\begin{array}{l}400 \mathrm{~mm} \text { (Brake-drum), spring } \\
\text { balance load adjusted with Screw } \\
\text { Load }\end{array}$ \\
\hline
\end{tabular}

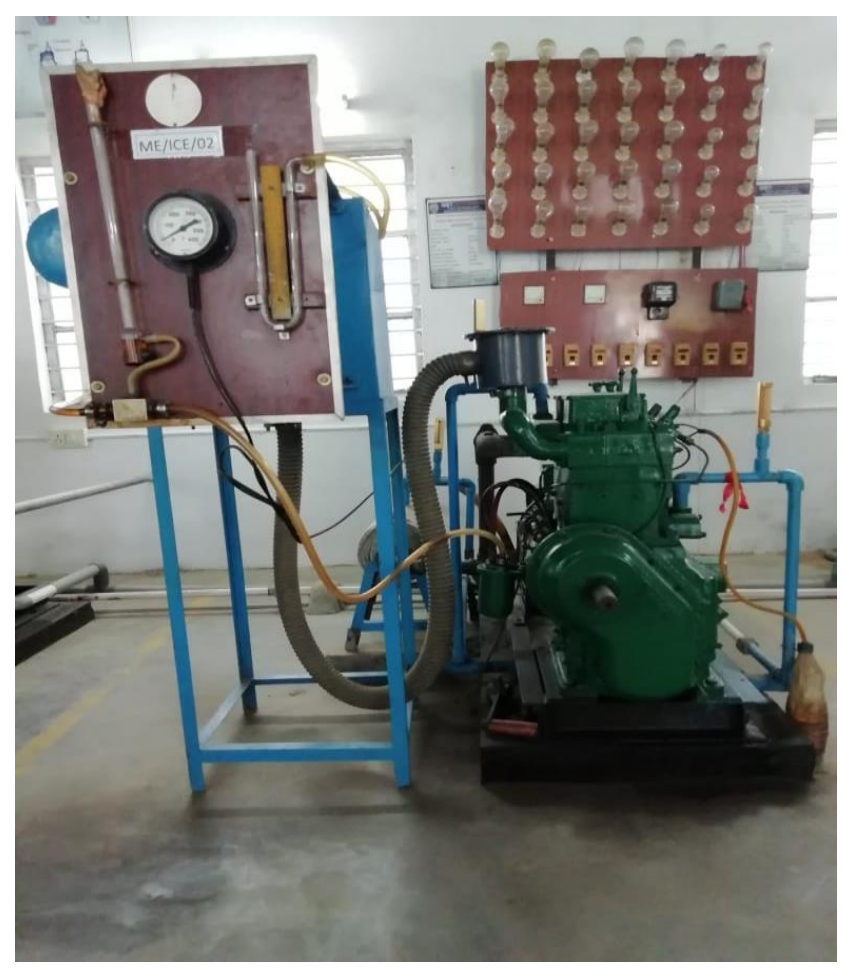

Fig.1: Experimental Setup

With the tested engine (fig.1), an electrical dynamometer and a spring load balancing device (fig.2) were connected for the measurement of indicated power and brake power which are being operated at variable load conditions. A 3 liter capacity of commercial fuel tank was used for storing the prepared biodiesel blends with diesel oil. The fuel was pumped through the injector pump under the action of gravity and the fuel flow rate (volumetric) was measured by using a burette with labeled scale and a stop watch for measuring time. The EGT (exhaust gas temperature) was measured by using thermocouple wires which are connected to a temperature indicator. A smoke meter and gas analyzer was connected to the exhaust manifold of the engine in order to measure the exhaust gas emissions. The results were found out by taking the readings with varying the load conditions.

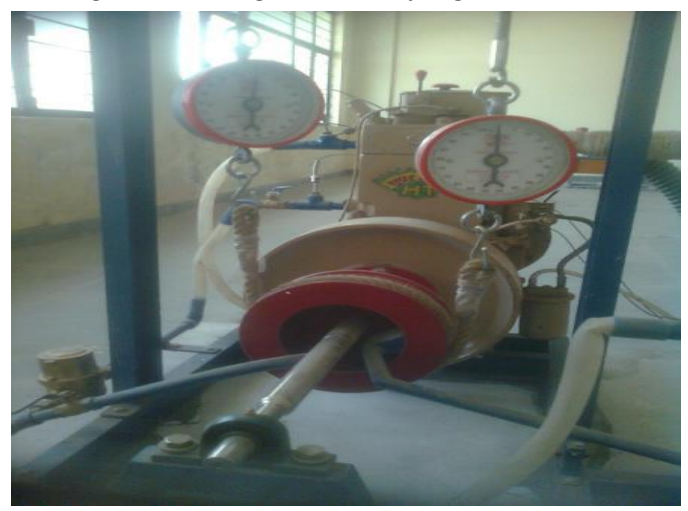

Fig.2: Load Balance

\section{RESULTS AND DISCUSSION}

The experiments were conducted in the specified diesel engine with preheated Sunflower Bio Diesel (20\% blend) at different loads. Various performance parameters were being analyzed which are discussed below along with graph 3.1.

\section{A. Brake specific fuel consumption}

It has been found that, the BSFC for given diesel engine running with pure diesel fuel is $0.283 \mathrm{~kg} / \mathrm{kWh}$ at full load condition. From the above graph it can be noticed that BSFC is enhanced consequently up to $0.451 \mathrm{~kg} / \mathrm{kWh}$ at minimum load condition. When the diesel oil is replaced by sunflower Bio Diesel blend (B20), a slight improvement in BSFC is observed. i.e. $0.538 \mathrm{~kg} / \mathrm{kWh}$. Again when replaced by preheating the blend up to $60^{\circ} \mathrm{C}$, it decreases to 0.498 $\mathrm{kg} / \mathrm{kWh}$. Most probably this happened due to increase in viscosity of the used blend that leads to better atomization of fuel particles which consequently accelerates the combustion process.

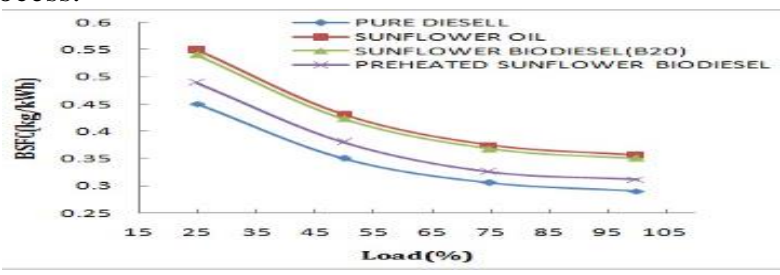

Fig. 3: Load Vs. BSFC For Fuels

\section{B. Brake Specific Energy Consumption}

The below fig. 4 gives us the information regarding load variations against the BSEC for the test fuels. It was observed that the BSEC for only refined sunflower oil is the highest i.e.20.98 MJ/kWh which is quite high. When it is replaced by the blended biodiesel, there is a considerable decrease of BSEC up to 19.56 . It was further reduced by $0.4 \mathrm{MJ} / \mathrm{kWh}$ as compared to that of sunflower biodiesel when preheating blend (B20) is used. When only diesel oil was used, the $\mathrm{BSFC}$ is found as 16.58 $\mathrm{MJ} / \mathrm{kWh}$. 


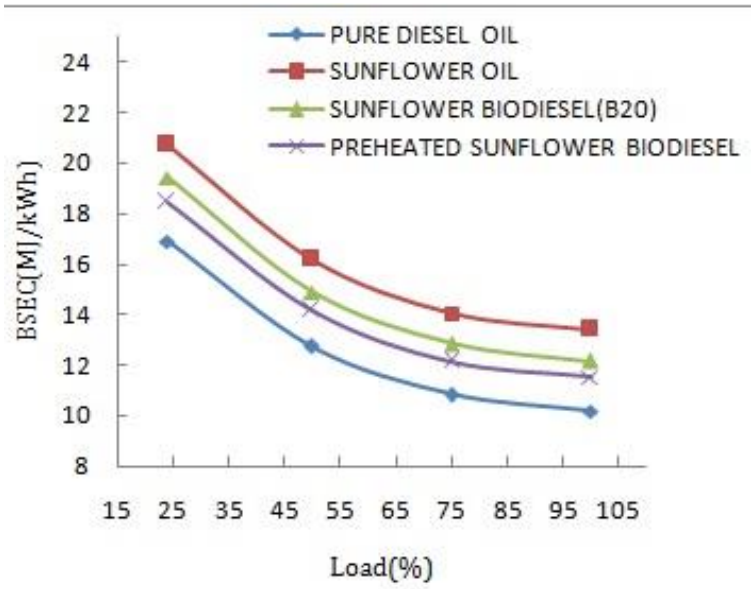

Fig. 4: Load Vs. BSEC For Test Fuels

\section{Brake Thermal Efficiency ( $\eta_{b t h)}$}

Generally brake thermal efficiency relates to the overall performance of the engine at variable load conditions. According to the experimented data, a graph is being plotted between load and BTH as shown in fig.5. When only commercial diesel oil was used, the BTE ( $\left.\eta_{b t h}\right)$ was found as $32.2 \%$. When replaced by sunflower biodiesel, it is reduced to $27.3 \%$ because of the heat loss from the combustion chamber. Again with the use of sunflower biodiesel blend with preheating, a small percentage increase of $1.2 \%$ as compared to that of without heating the blend. The efficiency with preheating the blend was found as 28.5.How ever this value of efficiency is still lower by $1.6 \%$ as compared to that of diesel operation.

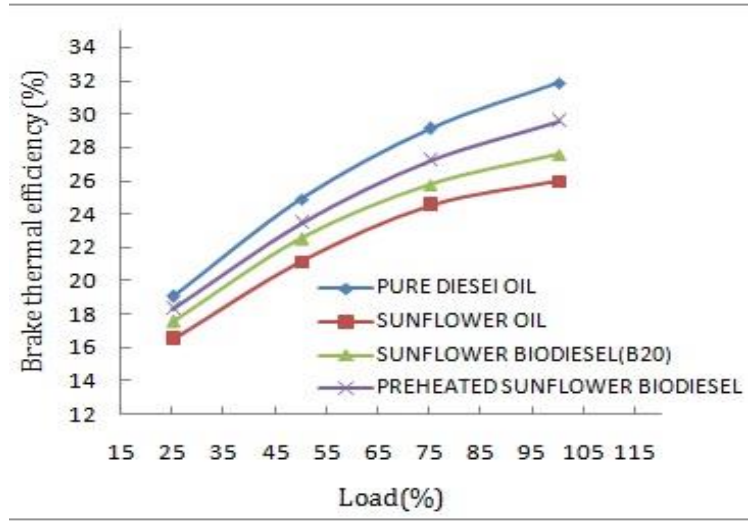

Fig.5: Load Vs. Brake Thermal Efficiency For Test FuelsD. Exhaust Gas Temperature

The purpose of measuring and comparing temperature of exhaust gas is to understand the effective utilization of heat energy by the engine. When the combustion is ineffective the heat energy conversion into work will be less indicating lower thermal efficiency, It Is inferred from fig. 6 that the temperature of the exhaust is $355^{\circ} \mathrm{C}$ when Diesel is used and it is increased to $419{ }^{\circ} \mathrm{C}$ when Diesel is replaced by Sunflower Biodiesel. A drop in $16{ }^{\circ} \mathrm{C}$ is noticed when the preheated blend B 20 is used.

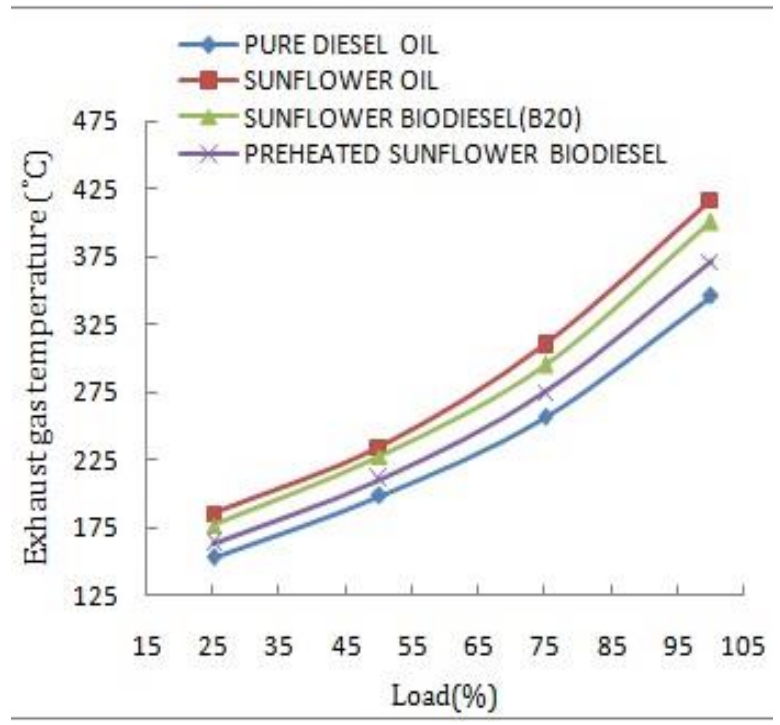

Fig.6: Load Vs. EGT For Test Fuels

\section{E. Nitrogen oxide (NOx)}

The following graph (fig.7) reveals variation of loads against the NOx emissions. The corresponding emission was calculated by using a gas analyzer connected to the exhaust side of the test engine along with the load test. It is found that the discussed concern of diesel used as fuel in rated engine was having NOx (2120 ppm) higher than that of blended oil B20 which is $1889 \mathrm{ppm}$.

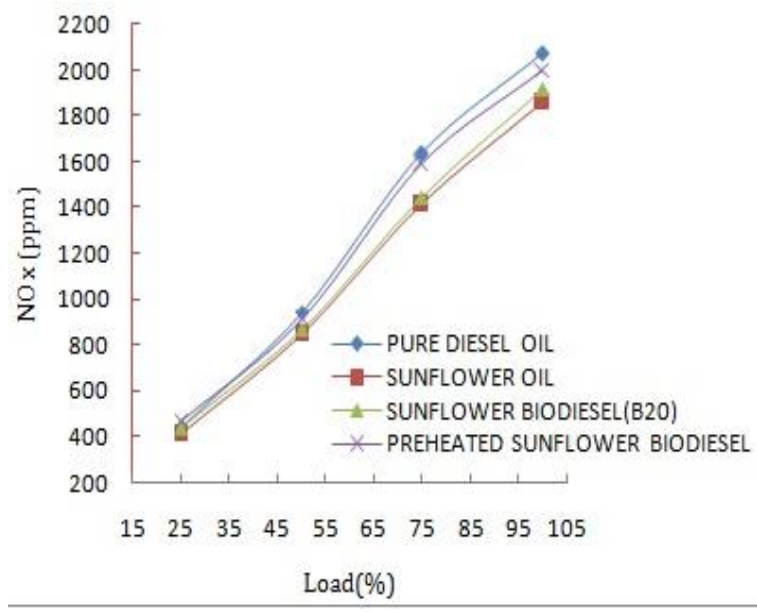

Fig.7: Load Vs. Nox For Test Fuels

Again with preheating of the selected blend, the amount of NOx is a trade-off between diesel oil and sunflower biodiesel which is $1982 \mathrm{ppm}$. Generally it is not advisable to use only sunflower oil because of its high viscosity and low Cetane number.

\section{F. Unburned Hydrocarbons}

It is noted from the graph that $196 \mathrm{ppm}$ of unburnt Hydrocarbons was found from the exhaust gas with Diesel fuel. It is increased to $209 \mathrm{ppm}$ when sunflower biodiesel is used indicating the incomplete combustion. 


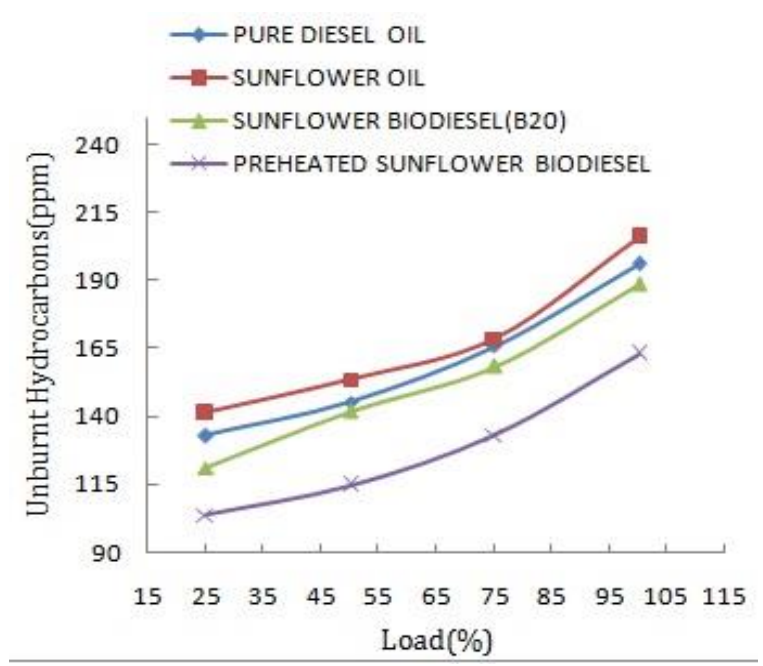

Fig.8: load Vs. Unburnt HC for different test fuels

A considerable decrease of $34 \mathrm{ppm}$ is noticed when using preheated blend as compared to B20 blend without heating.

\section{G. Carbon Monoxide}

The graph shown tells us the variation of loads against the carbon monoxide emissions. When Diesel is used in the specified engine, the $\mathrm{CO}$ emission was being calculated as 29 $\%$ by volume which is further increased by $11 \%$ more than that of blended biodiesel. And with preheating , a considerable decrease that is to $8 \%$ as compared with diesel oil .

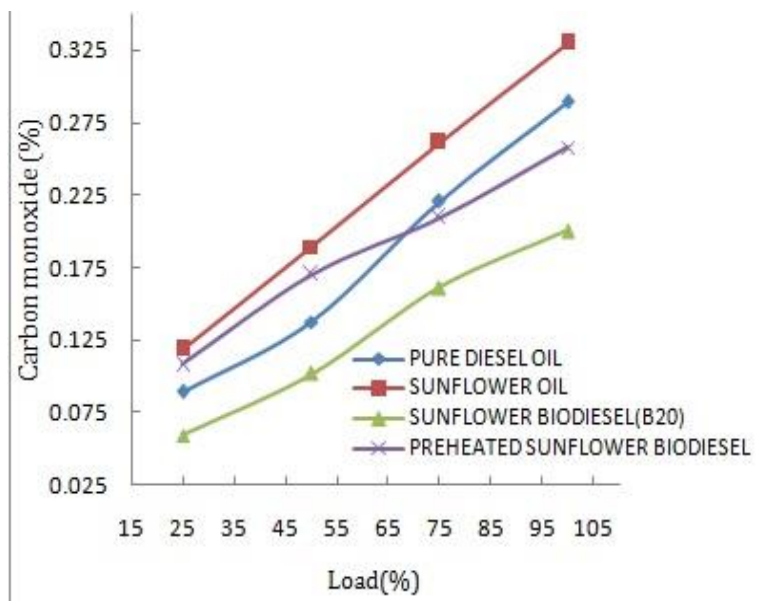

Fig.9: Load Vs. CO For Test Fuels

\section{H. Smoke}

It was found that the emission of smoke by using diesel oil is 3.05 BSU which was increased up to $3.3 \mathrm{BSU}$ when Sunflower oil is used. Further when it is replaced by blend B20,A reducing level of 2.9 was seen. Again it is reduced significantly when the blend is preheated i.e up to 2.65. So, it is very significant that when the oil is preheated ,the vaporization of the fuel is high and it helps the effective atomization of fuel ; so as to reduce the soot and smoke. These emissions were being measured by using a gas analyzer along with a smoke meter.

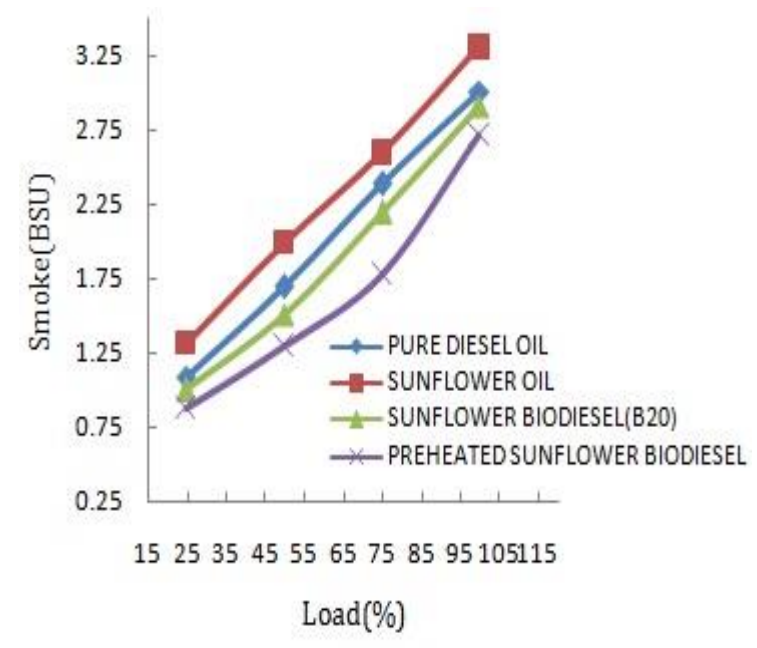

Fig.10: Load Vs. Smoke For Test Fuels

\section{CONCLUSION}

So, as various readings were taken in order to evaluate the parameters of these four illustrated tested fuels, many graphs were plotted with variable of loads against the performance parameters as well as emission parameters. Some advancement could be made when to determine the combustion, performance and emission parameters with preheated $\left(60^{\circ} \mathrm{C}\right)$ sunflower bio diesel oil is used as a test fuel The following conclusions were made from the above experimental analysis.

1) Firstly with preheating the blend up to the required temperature, the fuel consumption rate was found as much as lower than that of pure sunflower oil. But comparing to diesel oil, the BSFC was found a considerable decrease amount. So, it will be advisable if some natural additives will be added, it may be up to the point to that of diesel.

2) The various emissions are being analyzed with full load and partial load conditions. It was preferable and found effective to use the preheating blended oil in order to reduce various emissions, unburnt hydrocarbons as well as smoke levels.

3) The exhaust gas temperature of the given engine is low when diesel is used which is also found lower than that of preheated biodiesel blend. So, the EGT by using preheated blend is a trade- off in between diesel and biodiesel blend without preheating.

\section{REFERENCES}

1. Seid Yimer, Omprakash Sahu , "Optimization of Biodiesel Production from Waste Cooking Oil”, Sustainable Energy, 2014, Vol. 2, No. 3, pp 81-84.

2. M.M. Hasan, M.M. Rahman , Performance and emission characteristics of biodiesel-diesel blend and environmental and economic impacts of biodiesel production: A review, Renewable and Sustainable Energy (2017),vol. 74, pp 938-948.

3. R. Sindhu, G. Amba Prasad Rao, K. Madhu Murthy, "Effective reduction of NOx emissions from diesel engine using split injections", Alexandria Engineering Journal, 2017.

4. Mithun Das,Mouktik Sarkar, Amitava Datta, Apurba Kumar Santra, "Study on viscosity and surface tension properties of biodiesel-diese blends and their effects on spray parameters for CI engines", fuel (2018), vol. 220, pp 769-779 
5. Menelik Walle Mekonen, N.Sahoo“ Effect of fuel preheating with blended fuels and exhaust gas recirculation on diesel engine operating parameters" Renewable Energy Focus, Vol. 26, September 2018, Pages 58-70.

6. Venu Babu Borugadda,Ajay K. Dalai, Supratim Ghosh, "Effects of natural additives on performance of canola biodiesel and its structurally modified derivatives",Industrial crops and products,2018,vol. 125, pp 303-313.

7. Wang Y, Ou SY, Liu PZ, Tang SZ. "Comparison of two different processes to synthesize biodiesel by waste cooking oil" J Mol Catal A Chem 2006; 252:107e12.

8. M.M. Hasan, M.M. Rahman, and K. Kadirgama "A Review On Homogeneous Charge Compression Ignition Engine Performance Using Biodiesel-Diesel Blend Fuel 'International Journal ofAutomotive and Mechanical Engineering (IJAME) Volume 11, pp. 2199-2211,

9. Norrizal ustaffa, M. Faridies, Hanis zakaria, B.anshoo, "Preheated Biodiesel Derived from Vegetable oil on Performance and Emissions of Diesel Engines" Applied Mechanics and Materials Vols. 465-466 (2014) pp 285-290.

10.K.S.Shankar et al., MPFI gasoline engine combustion, performance and emission characteristics with LPG injection ,Volume 25, Energy, Issues 5-8,Pages 738-751,ISSN 0928-4931(2016)

11.SukumarPuhan, N. Vedaraman, Performance and emission study of Mahua oil (madhucaindica oil) ethyl ester in a 4-stroke natural aspirated direct injection diesel engine, Renewable Energy, Volume 30, Issue 8,Pages 1269-1278,ISSN 0960-1481(2013).

12.Daniel Wiznia., Modeling the Formation of Nox and Soot Emissions in a Diesel Engine at Different Humidity, International Journal of Green Energy ,vol. 9,pp. 815-828. (2012).

13.M.P Dorado, E Ballesteros, J.M Arnal, J Gómez, F.J López, “Exhaust emissions from a Diesel engine fueled with transesterified waste olive oil’,Fuel, Volume 82, Issue 11, Pages 1311-1315,ISSN 0016-2361(2012).

14.Cherng-Yuan Lin, Kuo-Hua Wang, Diesel engine performance and emission characteristics using three-phase emulsions as fuel,Fuel,Volume 83, Issues5,Pages 537-545,ISSN 0016-2361(2011).

15.Ramadhas A.S., Jayaraj S., MuraleedharanC, Theoretical modeling and experimental studies on biodiesel-fueled engine, Renewable Energy, 31 ,pp 1813-1826(2011)

\section{AUTHORS PROFILE}

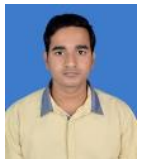

Ashok Kumar Mohapatra working as assistant professor, Department of mechanical engineering, GIET UNIVERSITY, Gunupur. He has completed M.Tech in heat power and thermal engineering from GIET university Gunupur. He has one year research experience in alternative fuel in IC engines .He is an active member of The institute of engineers(IE) ,International Society for Research and Development (ISRD) and International Association of Engineers (IAENG).

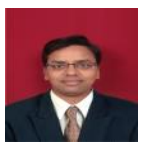

Ajit Kumar Senapati working as an associate professor, Department of mechanical engineering, GIET UNIVERSITY, Gunupur, Odisha. He has completed PhD from KIIT university. He has thirteen year teaching and research experience at GIET university. $\mathrm{He}$ is a life member of ISTE chapter, Institute of Engineers India(IEI),Computer society of India and Indian Institute of Welding.

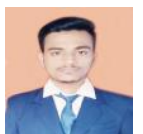

Govind Jha studying Bachelor in technology (Fourth year), Department of mechanical engineering at GIET university, Gunupur

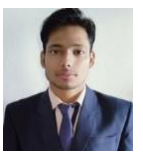

Chandan Kumar Sharma studying Bachelor in technology (Fourth year), Department of mechanical Engineering at GIET university, Gunupur .

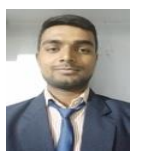

Prakash Kumar studying Bachelor in technology (Fourth year), Department of mechanical Engineering at GIET university, Gunupur. 